\title{
$B D N F$ Val66Met polymorphism and serum concentrations of BDNF with smoking in Thai males
}

\author{
K. Suriyaprom ${ }^{1}$, R. Tungtrongchitr ${ }^{2}$, K. Thawnashom ${ }^{1}$ and Y. Pimainog${ }^{1}$ \\ ${ }^{1}$ Faculty of Medical Technology, Rangsit University, Pathumthani, Thailand \\ ${ }^{2}$ Department of Tropical Nutrition and Food Science, \\ Faculty of Tropical Medicine, Mahidol University, Bangkok, Thailand \\ Corresponding author: K. Suriyaprom \\ E-mail: kanjana.su@rsu.ac.th
}

Genet. Mol. Res. 12 (4): 4925-4933 (2013)

Received March 7, 2013

Accepted August 18, 2013

Published October 24, 2013

DOI http://dx.doi.org/10.4238/2013.October.24.3

\begin{abstract}
Many studies have suggested that brain-derived neurotrophic factor (BDNF) is involved in the reward system of addiction, and that nicotine may induce alterations in $B D N F$ gene expression and its protein level within the mesocorticolimbic system. We investigated the BDNF levels and biochemical-hematological parameters of smoker and non-smoker groups, and examined the association of the Val66Met $B D N F$ gene polymorphism with BDNF serum levels and cigarette smoking. The study sample comprised 311 Thai volunteers (200 smokers; 111 non-smokers). The levels of serum BDNF and biochemical-hematological parameters were determined. The Val66Met $B D N F$ polymorphism was genotyped by the polymerase chain reaction-restriction fragment length polymorphism technique. The smoker group had significantly higher serum BDNF levels than the non-smoker group (8.3 vs 6.5 $\mathrm{ng} / \mathrm{mL}, \mathrm{P}<0.05)$. BDNF concentrations correlated positively with hemoglobin, hematocrit, red blood cell count, white blood cell count, platelet count, number of cigarettes smoked, and thiocyanate level
\end{abstract}


$(\mathrm{P}<0.05)$. No association was found between the $B D N F$ Val66Met genotype and the serum BDNF level. The $B D N F$ Val66Met polymorphism was not significantly associated with the smoking status of the Thai males in this study. Cigarette smoking may be one factor that determines the serum BDNF level, but the BDNF Val66Met polymorphism probably does not influence susceptibility to smoking among Thai males.

Key words: Cigarette smoking; Brain-derived neurotrophic factor; $B D N F$ Val66Met polymorphism; Hematological parameters

\section{INTRODUCTION}

Brain-derived neurotrophic factor (BDNF) is a member of the neurotrophic factor family, which plays a key role in the survival and differentiation of neurons, regenerative sprouting of damaged neurons, and modulation of chemical synapses (Soulé et al., 2006). BDNF influences serotonin and dopamine neurotransmission in the ventral tegumental area-nucleus accumbens pathway, both of which are involved in the reward system of addiction (Narita et al., 2003; Beuten et al., 2005). The region of chromosome 11p13, where the $B D N F$ gene is located, is likely to harbor susceptible genes for nicotine dependence (Li et al., 2003; Han et al., 2010). The valine (Val) 66 methionine (Met) polymorphism (rs6265) of the $B D N F$ gene is located on the 5'-BDNF precursor peptide (pro-BDNF) sequence. This single nucleotide polymorphism affects the intracellular trafficking of proBDNF and the secretion of the mature peptide with the Met allele, which is related to a decrease in the activity-dependent secretion of BDNF compared to the Val allele (Egan et al., 2003). Although some studies determined the association between cigarette smoking and BDNF concentration, as well as the Val66Met BDNF gene polymorphism, the results from these studies are inconsistent (Bhang et al., 2010; Zhang et al., 2010; Bus et al., 2011; Breetvelt et al., 2012). However, no studies have investigated the combination of the Val66Met $B D N F$ genotype and BDNF levels in smokers and non-smokers among Thai subjects. Therefore, the aims of this study were to detect the levels of BDNF and biochemical-hematological parameters in smoker and non-smoker groups, to determine whether the Val66Met $B D N F$ gene polymorphism is associated with BDNF serum levels and other variables, and to analyze any association between this $B D N F$ gene polymorphism and cigarette smoking.

\section{MATERIAL AND METHODS}

\section{Subjects}

Following approval by the Ethics Committee of Rangsit University, a convenience sample of 311 Thai volunteers (aged 21 to 62 years) were recruited from urban and suburban residential areas of Bangkok, Thailand. Cigarette smoking was more prevalent in Thai males than females (Vathesatogkit and Charoenca, 2011), and our study sample size was calculated to provide statistical confidence. The sample excluded the following subjects: 
those taking regular medication; those with psychiatric or neurological diseases, including substance dependence; and those with a history of diabetes mellitus, allergy, or liver, kidney, or cardiovascular disease that was confirmed by appropriate physical examination and laboratory tests. No subject was taking psychoactive medications or anti-inflammatory drugs. Of these 311 subjects, 200 were smokers, while the remaining 111 were non-smokers. All volunteers were interviewed about lifestyle pattern and medical history. Smoking characteristics - age at onset of smoking, number of cigarettes smoked, and duration of smoking (in years) - were recorded in detail.

The age, weight, and height of each subject were determined. About $10 \mathrm{~mL}$ venous blood was collected in the morning (between 8:00 and 9:00 am) after an overnight fast, and then venous blood samples were centrifuged after a clotting time of 30-60 min at 3000 $\mathrm{rpm}$ for $15 \mathrm{~min}$ at $4^{\circ} \mathrm{C}$ to obtain serum. Immediately after centrifugation, serum samples were divided into aliquots of $400 \mu \mathrm{L}$ and stored at $-80^{\circ} \mathrm{C}$ until the time of assay. Repeated freeze-thaw cycles were avoided. Serum was used to determine biochemical variables, i.e., total cholesterol, triglycerides, thiocyanate, and BDNF. Ethylenediaminetetraacetic acid (EDTA) blood was used to determine hematological variables, i.e., hemoglobin, hematocrit, red blood cell (RBC) count, white blood cell (WBC) count, and platelet count.

\section{Biochemical measurements}

Total cholesterol and triglycerides were measured using enzymatic methods by DADE Dimension ${ }^{\circledR}$ AR. WBC, RBC, and platelet counts and hemoglobin and hematocrit concentrations were also determined (Coulter Counter). Serum thiocyanate concentrations were assessed using the colorimetric method (Degiampietro et al., 1987). Serum BDNF levels were determined using an enzyme-linked immunosorbent assay protocol according to the manufacturer instructions (DBD00; R \& D Systems).

\section{Polymerase chain reaction-restriction fragment length polymorphism (PCR-RFLP) technique}

DNA was extracted from EDTA-treated whole blood using the Flexi Gene DNA kit (QIAGEN, Hilden, Germany). DNA fragments containing the Val66Met (G196A) BDNF gene polymorphism were amplified by PCR (PE Applied Biosystems). A pair of primers (forward: 5'-ATCCGAGGACAAGGTGGC-3' and reverse: 5'-CCTCATGGACATGTTTGCAG-3') was employed, and a $50-\mu \mathrm{L}$ PCR was performed according to the previously described protocol (Matsushita et al., 2004). Each reaction was digested with the restriction enzyme PmlI. Alleles were visualized as fragments of $300 \mathrm{bp}$ (A allele) and 180/120 bp ( $\mathrm{G}$ allele) by electrophoresis on an ethidium bromide-stained $2 \%$ agarose gel.

\section{Statistical analysis}

Statistical analysis was performed using SPSS for Windows version 11.5 (SPSS, Chicago, IL, USA). Median and 95\% confidence interval (CI) were calculated. The difference between the two groups was compared by the Mann-Whitney U-Wilcoxon rank sum $\mathrm{W}$-test. Statistical differences in genotype distributions between the two groups were as- 
sessed by the chi-square test. Spearman rank was used to calculate correlations among the variables. $\mathrm{P}<0.05$ was considered to be statistically significant.

\section{RESULTS}

The median and $95 \% \mathrm{CI}$ for age, weight, height, blood pressure, resting heart rate, and biochemical-hematological measurements in the smoker and non-smoker groups are shown in Table 1. No significant differences in age, weight, height, blood pressure, resting heart rate, lipids, hemoglobin, hematocrit, RBC, or platelet counts were observed between the two groups. The BDNF concentrations and WBC counts of the smokers were higher than those of the non-smokers $(\mathrm{P}<0.05)$. Age, weight, height, blood pressure, resting heart rate, and biochemical-hematological measurements of all subjects according to the Val66Met $B D N F$ polymorphism genotype are shown in Table 2 . Subjects were divided into either the Val/Val homozygote genotype or those carrying the Met allele (Met/Val and Met/ Met). The results showed that variables of these genotypes did not differ $(\mathrm{P}>0.05)$. The genotype frequencies of all subjects are shown in Table 3. The genotypes of the Val66Met polymorphism were in Hardy-Weinberg equilibrium $(\mathrm{P}=0.525)$. The genotype distributions of the $B D N F$ gene polymorphism did not differ significantly between smokers and non-smokers $(\mathrm{P}=0.421)$. Subsequently, we compared the characteristics of the smokers across the Val66Met genotypes (Table 4). The age at onset of smoking, number of cigarettes smoked, duration of smoking, and thiocyanate concentration did not differ between the Val/Val genotype and the Met allele carriers $(\mathrm{P}>0.05)$. The relationships between BDNF and other parameters were also determined for all subjects (Table 5). BDNF concentrations correlated positively with hemoglobin $(\mathrm{r}=0.189, \mathrm{P}=0.002)$, hematocrit $(\mathrm{r}=0.178$, $\mathrm{P}=0.003)$, RBC count $(\mathrm{r}=0.274, \mathrm{P}<0.001) \mathrm{WBC}$ count $(\mathrm{r}=0.185, \mathrm{P}=0.002)$, platelet count $(\mathrm{r}=0.232, \mathrm{P}<0.001)$, thiocyanate $(\mathrm{r}=0.176, \mathrm{P}=0.005)$, and number of cigarettes smoked $(\mathrm{r}=0.149, \mathrm{P}=0.014)$.

Table 1. Median and $95 \%$ confidence interval $(95 \% \mathrm{CI})$ for age, weight, height, blood pressure, resting heart rate, and biochemical-hematological measurements for smokers and non-smokers.

\begin{tabular}{|c|c|c|c|c|c|}
\hline \multirow{3}{*}{$\begin{array}{l}\text { Variables } \\
\text { Age (years) }\end{array}$} & \multicolumn{4}{|c|}{ Total subjects $(\mathrm{N}=311)$} & \multirow{3}{*}{$\begin{array}{c}\text { P value } \\
0.080\end{array}$} \\
\hline & \multicolumn{2}{|c|}{ Smokers $(N=200)$} & \multicolumn{2}{|c|}{ Non-smokers $(\mathrm{N}=111)$} & \\
\hline & 37.0 & $34.0-40.0$ & 36.0 & $33.5-38.0$ & \\
\hline Weight (kg) & 63.5 & $61.0-64.5$ & 65.1 & $63.0-67.2$ & 0.078 \\
\hline Height $(\mathrm{cm})$ & 166.0 & $165.0-166.5$ & 166.5 & $165.0-167.5$ & 0.512 \\
\hline Systolic blood pressure $(\mathrm{mmHg})$ & 120.0 & $119.0-120.0$ & 120.0 & $117.0-121.0$ & 0.936 \\
\hline Diastolic blood pressure $(\mathrm{mmHg})$ & 79.0 & $74.0-80.0$ & 76.0 & $74.0-80.0$ & 0.835 \\
\hline Resting heart rate (bpm) & 72.0 & $71.0-75.0$ & 70.0 & $68.0-73.0$ & 0.139 \\
\hline Total cholesterol (mg/dL) & 200.0 & $190.0-210.0$ & 203.0 & $195.0-210.0$ & 0.665 \\
\hline Triglycerides $(\mathrm{mg} / \mathrm{dL})$ & 120.0 & $111.0-133.0$ & 126.0 & $115.0-132.0$ & 0.732 \\
\hline Hemoglobin $(\mathrm{g} / \mathrm{dL})$ & 14.8 & $14.7-15.0$ & 14.9 & $14.6-15.1$ & 0.801 \\
\hline Hematocrit $(\%)$ & 45.0 & $44.2-45.6$ & 44.5 & $44.0-45.0$ & 0.287 \\
\hline $\operatorname{RBC}\left(10^{12} / \mathrm{L}\right)$ & 5.3 & $5.2-5.4$ & 5.2 & $5.1-5.3$ & 0.086 \\
\hline WBC $\left(10^{9} / \mathrm{L}\right)$ & 7.0 & $6.7-7.5$ & 6.3 & $5.8-6.6$ & $0.000^{*}$ \\
\hline Platelet count $\left(10^{9} / \mathrm{L}\right)$ & 249.0 & $241.7-259.3$ & 257.0 & $242.0-274.5$ & 0.342 \\
\hline $\mathrm{BDNF}(\mathrm{ng} / \mathrm{mL})$ & 8.3 & $7.7-9.1$ & 6.5 & $5.6-8.3$ & $0.034 *$ \\
\hline
\end{tabular}

$\mathrm{RBC}=$ red blood cell count; $\mathrm{WBC}=$ white blood cell count; $\mathrm{BDNF}=$ brain-derived neurotrophic factor. $* \mathrm{P}<0.05$ by Mann-Whitney U-Wilcoxon rank sum W-test (two-tailed). 
Table 2. Age, weight, height, blood pressure, resting heart rate, and biochemical-hematological measurements for all subjects by the $B D N F$ genotype polymorphism at position Val66Met.

\begin{tabular}{|c|c|c|c|c|c|}
\hline \multirow{3}{*}{$\begin{array}{l}\text { Variables } \\
\text { Age (years) }\end{array}$} & \multicolumn{4}{|c|}{ Total subjects $(\mathrm{N}=311)$} & \multirow{3}{*}{$\begin{array}{r}\text { P value } \\
0.890\end{array}$} \\
\hline & \multicolumn{2}{|c|}{ Met/Val+Met/Met $(\mathrm{N}=219)$} & \multicolumn{2}{|c|}{$\mathrm{Val} / \mathrm{Val}(\mathrm{N}=92)$} & \\
\hline & 36.0 & $35.0-38.0$ & 37.5 & $33.0-40.0$ & \\
\hline Weight (kg) & 64.0 & $62.2-65.3$ & 63.6 & $61.7-65.9$ & 0.675 \\
\hline Height $(\mathrm{cm})$ & 166.0 & $164.5-166.5$ & 166.5 & $165.5-168.0$ & 0.367 \\
\hline Systolic blood pressure (mmHg) & 120.0 & $118.0-120.0$ & 120.0 & $119.0-120.0$ & 0.758 \\
\hline Diastolic blood pressure $(\mathrm{mmHg})$ & 78.0 & $75.0-80.0$ & 77.0 & $74.0-80.0$ & 0.491 \\
\hline Resting heart rate (bpm) & 72.0 & $70.0-72.0$ & 73.0 & $72.0-75.0$ & 0.214 \\
\hline Total cholesterol (mg/dL) & 202.0 & $192.0-210.0$ & 201.0 & $191.0-209.0$ & 0.952 \\
\hline Triglycerides (mg/dL) & 129.0 & $120.0-136.0$ & 119.0 & $106.0-131.0$ & 0.234 \\
\hline Hemoglobin $(\mathrm{g} / \mathrm{dL})$ & 14.8 & $14.7-15.0$ & 14.9 & $14.5-15.1$ & 0.961 \\
\hline Hematocrit (\%) & 44.6 & $44.2-45.1$ & 44.6 & $44.1-45.4$ & 0.829 \\
\hline $\mathrm{RBC}\left(10^{12} / \mathrm{L}\right)$ & 5.2 & $5.1-5.3$ & 5.2 & $5.1-5.3$ & 0.764 \\
\hline $\mathrm{WBC}\left(10^{9} / \mathrm{L}\right)$ & 6.8 & $6.5-7.0$ & 6.9 & $6.1-7.4$ & 0.979 \\
\hline Platelet count $\left(10^{9} / \mathrm{L}\right)$ & 255.0 & $244.2-265.8$ & 245.0 & $231.5-257.5$ & 0.088 \\
\hline BDNF (ng/mL) & 7.8 & $6.8-8.2$ & 8.2 & $6.1-9.0$ & 0.344 \\
\hline
\end{tabular}

Data are reported as median and 95\% confidence interval (95\%CI). ${ }^{a}$ Mann-Whitney U-Wilcoxon rank sum W-test (two-tailed). $\mathrm{RBC}=$ red blood cell count; $\mathrm{WBC}=$ white blood cell count; $\mathrm{BDNF}=$ brain-derived neurotrophic factor.

Table 3. Genotype frequencies of the $B D N F$ gene polymorphism at position Val66Met in all subjects $(\mathrm{N}=311)$.

\begin{tabular}{lccc}
\hline$B D N F$ gene polymorphism Val66Met & \multicolumn{2}{c}{ Genotype frequencies } & $P_{\text {value }}$ \\
\cline { 2 - 3 } & Smoking $(\mathrm{N}=200)$ & Non-smoking $(\mathrm{N}=111)$ & 0.421 \\
\hline Met/Met+Val/Met & $72.0 \%$ & $67.6 \%$ & $\mathrm{~N}=75$ \\
& $\mathrm{~N}=144$ & $32.4 \%$ & \\
Val/Val & $28.0 \%$ & $\mathrm{~N}=36$ \\
\end{tabular}

${ }^{\mathrm{a} C h i}$-square test.

Table 4. Characteristics of smoking subjects by the Val66Met genotype.

\begin{tabular}{lccc}
\hline Variables Val66Met & \multicolumn{2}{c}{$B D N F$ gene polymorphism } & P value \\
\cline { 2 - 3 } & Val/Val $(\mathrm{N}=56)$ & Met/Met+Val/Met $(\mathrm{N}=144)$ & 0.251 \\
\hline Thiocyanate $(\mu \mathrm{M})$ & 57.2 & 65.2 & $0.5-75.1$ \\
Number of cigarettes smoked per day (cigarettes/day) & $45.2-67.8$ & 16.0 & 0.642 \\
& $10.0-20.0$ & $10.0-20.0$ & 0.125 \\
Age started smoking (years) & 19.0 & 18.0 & 0.215 \\
& $18.0-20.0$ & $17.0-18.5$ & 20.5 \\
Duration of smoking (years) & 18.5 & $15.0-24.0$ & 0 \\
\hline
\end{tabular}

${ }^{a}$ Mann-Whitney U-Wilcoxon rank sum W-test (two-tailed).

Table 5. Correlation coefficients of serum BDNF levels with other parameters.

\begin{tabular}{|c|c|c|c|c|c|c|c|c|c|}
\hline Variables & Age & Weight & Height & $\begin{array}{l}\text { Systolic blood } \\
\text { pressure }\end{array}$ & $\begin{array}{l}\text { Diastolic blood } \\
\text { pressure }\end{array}$ & $\begin{array}{l}\text { Resting } \\
\text { heart rate }\end{array}$ & Triglycerides & $\begin{array}{c}\text { Total } \\
\text { cholesterol }\end{array}$ & \\
\hline \multicolumn{10}{|l|}{ BDNF } \\
\hline$r$ & -0.004 & 0.018 & -0.010 & -0.004 & -0.028 & 0.008 & 0.103 & -0.010 & \\
\hline Pvalue & 0.947 & 0.769 & 0.873 & 0.951 & 0.654 & 0.899 & 0.101 & 0.865 & \\
\hline Variables & Hemoglobin & Hematocrit & $\mathrm{RBC}$ & WBC & Platelet count & Thiocyanate & $\begin{array}{c}\text { Number of } \\
\text { cigarettes smoked } \\
\text { per day }\end{array}$ & $\begin{array}{l}\text { Duration of } \\
\text { smoking }\end{array}$ & $\begin{array}{l}\text { Age started } \\
\text { smoking }\end{array}$ \\
\hline \multicolumn{10}{|l|}{ BDNF } \\
\hline $\mathrm{r}$ & $0.189 * *$ & $0.178 * *$ & $0.274^{* *}$ & $0.185^{* *}$ & $0.232 * *$ & $0.176^{* *}$ & $0.149^{*}$ & -0.005 & -0.011 \\
\hline$P$ value & 0.002 & 0.003 & $<0.001$ & 0.002 & $<0.001$ & 0.005 & 0.014 & 0.935 & 0.863 \\
\hline
\end{tabular}

*Correlation is significant at 0.05 level. ${ }^{* *}$ Correlation is significant at 0.01 level. $\mathrm{RBC}=$ red blood cell count; $\mathrm{WBC}=$ white blood cell count; $\mathrm{BDNF}=$ brain-derived neurotrophic factor. 


\section{DISCUSSION}

This study showed that the BDNF concentrations of the smokers were higher than those of the non-smokers. We did not identify a link between smoking among Thai males and the $B D N F$ Val66Met polymorphism. Moreover, this study was unable to find a relationship between the BDNF level and the BDNF Val66Met genotype in Thai smokers. The BDNF protein is important for neuronal growth, proliferation, and repair, as well as modulation of synaptic plasticity in several neurotransmitter systems, including the serotonin and dopamine systems (Mamounas et al., 1995; Narita et al., 2003). Peripheral BDNF levels are widely used as an indicator of the same brain parameter (Karege et al., 2002), but the regulation of BDNF levels in the peripheral blood is not fully understood (Gass and Hellweg, 2010). Recent studies with large sample sizes revealed that current smokers had significantly higher serum BDNF levels than non-smokers (Zhang et al., 2010; Bus et al., 2011, 2012). These findings have been confirmed by this study. An opposite effect has been reported on plasma BDNF levels in two previous studies, which had small sample sizes of smokers (Kim et al., 2007; Bhang et al., 2010). Chan et al. (2008) reported no significant difference in serum BDNF levels between smoker and non-smoker groups. This apparent inconsistency may be explained by the altered platelet function of smokers (Winther and Fornitz, 1999) and the size of the sample that was studied. Platelets represent a major storage site for BDNF in the peripheral blood (Fujimura et al., 2002), while diurnal rhythm BDNF levels were found in plasma but not in serum (Piccinni et al., 2008). Plasma BDNF concentrations significantly decrease with increases in age or weight, whereas platelet or serum levels do not seem to change (Lommatzsch et al., 2005). Moreover, our finding is consistent with that of Iughetti et al. (2011), who found that BDNF was positively correlated with platelet count. Most preclinical studies have shown that nicotine induces BDNF and upregulates BDNF receptors in the rat brain (Kenny et al., 2000; Correll et al., 2009). Gestational IV nicotine produces elevated BDNF levels in the mesocorticolimbic dopamine system of adolescent rat offspring (Harrod et al., 2011). Balfour and Ridley (2000) showed that chronic nicotine treatment decreases hippocampal 5-hydroxytryptamine (5-HT) overflow. It is possible, therefore, that a decrease in 5-HT receptor activation may be one mechanism by which chronic nicotine treatment increases BDNF expression (Vaidya et al., 1997). The $\beta$-arrestin-2 protein appears to play a major role in both nicotine sensitization and the effects of nicotine on BDNF in the nucleus accumbens, suggesting that this protein is important in nicotine's effects on synaptic plasticity in a brain region (Correll et al., 2009). Repeated nicotine administration results in the upregulation of BDNF and triggers a mechanism that modulates nicotine-dependent dopamine release as well as the dopamine D3 receptor (Kenny et al., 2000; Le Foll et al., 2003). Apart from dopamine, BDNF has been shown to promote the survival and differentiation of the serotonergic system (Mamounas et al., 1995; Eaton and Whittemore, 1996). Zhang et al. (2010) detected increased BDNF serum levels in smokers, and BDNF levels were further increased with increases in cigarette consumption; these results are consistent with those of our study. Therefore, it is possible that nicotine-stimulated increases in BDNF levels may contribute to synaptic rearrangements that are involved in the development and maintenance of the smoking habit.

The Val66Met polymorphism of the $B D N F$ gene was chosen for this study because this polymorphism affects the intracellular trafficking of pro-BDNF and the secretion of the 
mature peptide. Egan et al. (2003) reported that Met allele carriers have reduced secretion of mature BDNF; additionally, subjects who are Met allele carriers might be at risk of developing small hippocampal volumes and may be susceptible to major depressive disorders (Frodl et al., 2007). In healthy Korean subjects, decreased BDNF levels were significantly associated with Met allele carriers (Bhang et al., 2011). However, Lang et al. (2009) found high BDNF serum levels in healthy Met allele subjects. The effect of an association between the $B D N F$ Val66Met genotype and serum BDNF levels was not detected in our study, and our data agree with data from Terracciano et al. (2011).

The characteristics of the smoking subjects did not differ between the Val/Val genotype and Met allele carriers. In addition, no association was found between the $B D N F$ Val66Met genotype and smoking among Thai males. These findings are consistent with those from studies of a Dutch population (Breetvelt et al., 2012), German Caucasians (Montag et al., 2008), and African-Americans (Beuten et al., 2005). In European-American males, the BDNF Val66Met gene polymorphism was significantly associated with smoking, but the results were no longer significant after adjusting for multiple tests (Beuten et al., 2005). On the other hand, adult males with the Val allele in the $B D N F$ gene were at increased risk of smoking in the Han Chinese population with schizophrenia (Wang et al., 2007). Lang et al. (2007) found a link between smoking and the Met allele in the $B D N F$ gene of healthy volunteers. Reasons for the inconsistencies in the genetic association studies include the effects of ethnic stratification. Therefore, our findings imply that the $B D N F$ Val66Met gene polymorphism may not play a major role in determining smoking behaviors among Thai males.

In conclusion, this is the first study to investigate the association between the Val66Met $B D N F$ gene polymorphism and serum BDNF levels relative to smoking status among male Thai subjects. This study found the serum BDNF concentrations of the smokers to be higher than those of the non-smokers. There was no association between the BDNF Val66Met genotype and serum BDNF level or smoking status among the Thais who were sampled. Furthermore, no linkage was found between the characteristics of the smokers and the Val66Met genotype. Therefore, the Val66Met $B D N F$ gene polymorphism is unlikely to be associated with being vulnerable to smoking behavior. It should be kept in mind that the genetic tendency to smoke probably results from many genes, each one contributing a small part in the overall risk of smoking. Further studies should seek to determine the interaction effects of the $B D N F$ gene with other genes that are involved in smoking neurotransmitter systems.

\section{ACKNOWLEDGMENTS}

The authors wish to express their sincere thanks to all volunteers, staff of the Faculty of Medical Technology, Rangsit University, and staff of the Department of Tropical Nutrition and Food Science, Faculty of Tropical Medicine, Mahidol University, for their cooperation in this research. Thanks to Mr. Paul Adams for reading the manuscript. Research supported by funds from the Medical Technology Professional Alliance Against Tobacco (\#01/2554) and the Rangsit University, Thailand.

\section{REFERENCES}

Balfour DJ and Ridley DL (2000). The effects of nicotine on neural pathways implicated in depression: a factor in nicotine addiction? Pharmacol. Biochem. Behav. 66: 79-85. 
Beuten J, Ma JZ, Payne TJ, Dupont RT, et al. (2005). Significant association of BDNF haplotypes in EuropeanAmerican male smokers but not in European-American female or African-American smokers. Am. J. Med. Genet. B Neuropsychiatr. Genet. 139B: 73-80.

Bhang SY, Choi SW and Ahn JH (2010). Changes in plasma brain-derived neurotrophic factor levels in smokers after smoking cessation. Neurosci. Lett. 468: 7-11.

Bhang S, Ahn JH and Choi SW (2011). Brain-derived neurotrophic factor and serotonin transporter gene-linked promoter region genes alter serum levels of brain-derived neurotrophic factor in humans. J. Affect. Disord. 128: 299-304.

Breetvelt EJ, Numans ME, Aukes MF, Hoeben W, et al. (2012). The association of the alpha-5 subunit of the nicotinic acetylcholine receptor gene and the brain-derived neurotrophic factor gene with different aspects of smoking behavior. Psychiatr. Genet. 22: 96-98.

Bus BA, Molendijk ML, Penninx BJ, Buitelaar JK, et al. (2011). Determinants of serum brain-derived neurotrophic factor. Psychoneuroendocrinology 36: 228-239.

Bus BA, Tendolkar I, Franke B, de Graaf J, et al. (2012). Serum brain-derived neurotrophic factor: determinants and relationship with depressive symptoms in a community population of middle-aged and elderly people. World J. Biol. Psychiatr. 13: 39-47.

Chan KL, Tong KY and Yip SP (2008). Relationship of serum brain-derived neurotrophic factor (BDNF) and healthrelated lifestyle in healthy human subjects. Neurosci. Lett. 447: 124-128.

Correll JA, Noel DM, Sheppard AB, Thompson KN, et al. (2009). Nicotine sensitization and analysis of brain-derived neurotrophic factor in adolescent beta-arrestin-2 knockout mice. Synapse 63: 510-519.

Degiampietro P, Peheim E, Drew D, Graf H, et al. (1987). Determination of thiocyanate in plasma and saliva without deproteinisation and its validation as a smoking parameter. J. Clin. Chem. Clin. Biochem. 25: 711-717.

Eaton MJ and Whittemore SR (1996). Autocrine BDNF secretion enhances the survival and serotonergic differentiation of raphe neuronal precursor cells grafted into the adult rat CNS. Exp. Neurol. 140: 105-114.

Egan MF, Kojima M, Callicott JH, Goldberg TE, et al. (2003). The BDNF val66met polymorphism affects activitydependent secretion of BDNF and human memory and hippocampal function. Cell 112: 257-269.

Frodl T, Schule C, Schmitt G, Born C, et al. (2007). Association of the brain-derived neurotrophic factor Val66Met polymorphism with reduced hippocampal volumes in major depression. Arch. Gen. Psychiatr. 64: 410-416.

Fujimura H, Altar CA, Chen R, Nakamura T, et al. (2002). Brain-derived neurotrophic factor is stored in human platelets and released by agonist stimulation. Thromb. Haemost. 87: 728-734.

Gass P and Hellweg R (2010). Peripheral brain-derived neurotrophic factor (BDNF) as a biomarker for affective disorders? Int. J. Neuropsychopharmacol. 13: 1-4.

Han S, Gelernter J, Luo X and Yang BZ (2010). Meta-analysis of 15 genome-wide linkage scans of smoking behavior. Biol. Psychiatr. 67: 12-19.

Harrod SB, Lacy RT, Zhu J, Hughes BA, et al. (2011). Gestational IV nicotine produces elevated brain-derived neurotrophic factor in the mesocorticolimbic dopamine system of adolescent rat offspring. Synapse 65: 1382-1392.

Iughetti L, Casarosa E, Predieri B, Patianna V, et al. (2011). Plasma brain-derived neurotrophic factor concentrations in children and adolescents. Neuropeptides 45: 205-211.

Karege F, Schwald M and Cisse M (2002). Postnatal developmental profile of brain-derived neurotrophic factor in rat brain and platelets. Neurosci. Lett. 328: 261-264.

Kenny PJ, File SE and Rattray M (2000). Acute nicotine decreases, and chronic nicotine increases the expression of brainderived neurotrophic factor mRNA in rat hippocampus. Brain Res. Mol. Brain Res. 85: 234-238.

Kim TS, Kim DJ, Lee H and Kim YK (2007). Increased plasma brain-derived neurotrophic factor levels in chronic smokers following unaided smoking cessation. Neurosci. Lett. 423: 53-57.

Lang UE, Sander T, Lohoff FW, Hellweg R, et al. (2007). Association of the met66 allele of brain-derived neurotrophic factor (BDNF) with smoking. Psychopharmacology 190: 433-439.

Lang UE, Hellweg R, Sander T and Gallinat J (2009). The Met allele of the BDNF Val66Met polymorphism is associated with increased BDNF serum concentrations. Mol. Psychiatr. 14: 120-122.

Le Foll B, Diaz J and Sokoloff P (2003). Increased dopamine D3 receptor expression accompanying behavioral sensitization to nicotine in rats. Synapse 47: 176-183.

Li MD, Ma JZ, Cheng R, Dupont RT, et al. (2003). A genome-wide scan to identify loci for smoking rate in the Framingham Heart Study population. BMC Genet. 4 (Suppl 1): S103.

Lommatzsch M, Zingler D, Schuhbaeck K, Schloetcke K, et al. (2005). The impact of age, weight and gender on BDNF levels in human platelets and plasma. Neurobiol. Aging 26: 115-123.

Mamounas LA, Blue ME, Siuciak JA and Altar CA (1995). Brain-derived neurotrophic factor promotes the survival and sprouting of serotonergic axons in rat brain. J. Neurosci. 15: 7929-7939. 
Matsushita S, Kimura M, Miyakawa T, Yoshino A, et al. (2004). Association study of brain-derived neurotrophic factor gene polymorphism and alcoholism. Alcohol Clin. Exp. Res. 28: 1609-1612.

Montag C, Basten U, Stelzel C, Fiebach CJ, et al. (2008). The BDNF Val66Met polymorphism and smoking. Neurosci. Lett. 442: 30-33.

Narita M, Aoki K, Takagi M, Yajima Y, et al. (2003). Implication of brain-derived neurotrophic factor in the release of dopamine and dopamine-related behaviors induced by methamphetamine. Neuroscience 119: 767-775.

Piccinni A, Marazziti D, Del Debbio A, Bianchi C, et al. (2008). Diurnal variation of plasma brain-derived neurotrophic factor (BDNF) in humans: an analysis of sex differences. Chronobiol. Int. 25: 819-826.

Soulé J, Messaoudi E and Bramham CR (2006). Brain-derived neurotrophic factor and control of synaptic consolidation in the adult brain. Biochem. Soc. Trans. 34: 600-604.

Terracciano A, Piras MG, Lobina M, Mulas A, et al. (2011). Genetics of serum BDNF: Meta-analysis of the Val66Met and genome-wide association study. World J. Biol. Psychiatr. [Epub ahead of print].

Vaidya VA, Marek GJ, Aghajanian GK and Duman RS (1997). 5-HT2A receptor-mediated regulation of brain-derived neurotrophic factor mRNA in the hippocampus and the neocortex. J. Neurosci. 17: 2785-2795.

Vathesatogkit P and Charoenca N (2011). Tobacco control: lessons learnt in Thailand. Indian J. Public Health 55: 228-233.

Wang ZR, Zhou DF, Cao LY, Tan YL, et al. (2007). Brain-derived neurotrophic factor polymorphisms and smoking in schizophrenia. Schizophr. Res. 97: 299-301.

Winther K and Fornitz GG (1999). The effect of cigarette smoking and nicotine chewing gum on platelet function and fibrinolytic activity. J. Cardiovasc. Risk 6: 303-306.

Zhang XY, Xiu MH, Chen da C, Yang FD, et al. (2010). Nicotine dependence and serum BDNF levels in male patients with schizophrenia. Psychopharmacology 212: 301-307. 